\title{
On the Influence of Ultra-violet Rays upon the Protoplasmic Viscosity
}

By

\author{
N. Takamine
}

Received July 26, 1934

Some experiments were made to see whether or not a change in the viscosity of cytoplasm can be caused by irradiation by ultra-violet rays. The centrifuging method was employed to determine the occurrence of this change, the determination being made by comparing the number of replaced nuclei in the irradiated material with that of those in the control.

Root-tips of Vicia Faba, L. was used as material. The root-tips were exposed to the rays for $10 \mathrm{~m} ., 30 \mathrm{~m} ., 1 \mathrm{~h} ., 2 \mathrm{~h} ., 3 \mathrm{~h}$. and $4 \mathrm{~h}$, using the same method as that mentioned in my other paper. ${ }^{1)}$ In the case of $3 \mathrm{~h}$. and $4 \mathrm{~h}$. exposures. the material was not exposed to the rays continuously, but intermittently with certain invervals of time as shown in Table 1.

Table 1

\begin{tabular}{c|c|c|c|c|c}
\hline $\begin{array}{c}\text { Time of } \\
\text { exposure } \\
\text { in total }\end{array}$ & $\begin{array}{c}\text { Time of } \\
\text { first } \\
\text { exposure }\end{array}$ & $\begin{array}{c}\text { Time of } \\
\text { first } \\
\text { interval }\end{array}$ & $\begin{array}{c}\text { Time of } \\
\text { second } \\
\text { exposure }\end{array}$ & $\begin{array}{c}\text { Time of } \\
\text { second } \\
\text { interval }\end{array}$ & $\begin{array}{c}\text { Time of } \\
\text { third } \\
\text { exposure }\end{array}$ \\
\hline $3 \mathrm{~h}$. & $1 \mathrm{~h}$. & $3 \mathrm{~h}$. & $1 \mathrm{~h}$. & $3 \mathrm{~b}$. & $1 \mathrm{h.}$ \\
\hline $4 \mathrm{~h}$. & $2 \mathrm{~h}$. & $2 \mathrm{~h}$. & $2 \mathrm{~h}$ & & \\
\hline
\end{tabular}

In each experiment only 10 sections from each root-tip were observed. The results obtained are given in Table 2. In this table the actual number and percentage of nuclei closely in contact with the cell membrane, and of nuclei clearly apart from it (a certain number of nuclei displaced from their original position being included in this latter counting) are given.

1) TAKamine, N., On the Influence of Ultra-violet Rays upon the Frequency of Nuclear Division in Plants. (in the Press). 
Table 2

\begin{tabular}{|c|c|c|c|c|c|}
\hline \multirow{2}{*}{$\begin{array}{l}\text { Experi- } \\
\text { ment } \\
\text { series }\end{array}$} & \multirow{2}{*}{$\begin{array}{l}\text { Time of } \\
\text { exposure }\end{array}$} & \multicolumn{2}{|c|}{$\begin{array}{l}\text { Total number of nuclei } \\
\text { counted in } 10 \text { sections }\end{array}$} & \multicolumn{2}{|c|}{ The same in \% } \\
\hline & & in contact & apart & in contact & apart \\
\hline \multirow{2}{*}{ I } & $10 \mathrm{~m}$ & 851 & 60 & 93.4 & \multirow{2}{*}{-0.2} \\
\hline & control & 861 & 63 & 93.2 & \\
\hline \multirow{2}{*}{ II } & $30 \mathrm{~m}$. & 1161 & 98 & 92.3 & \multirow{2}{*}{+0.8} \\
\hline & control & 877 & 65 & 93.1 & \\
\hline \multirow{2}{*}{ III } & $1^{\text {h. }}$. & 1100 & 125 & 89.8 & \multirow{2}{*}{+3.2} \\
\hline & control & 1069 & 80 & 93.0 & \\
\hline \multirow{2}{*}{ IV } & $2^{\text {h. }}$ & 1002 & 136 & 88.0 & \multirow{2}{*}{+5.1} \\
\hline & control & 1361 & 99 & 93.1 & \\
\hline \multirow{2}{*}{ V } & $3^{\text {h. }}$. & 688 & 170 & 80.2 & \multirow{2}{*}{+7.9} \\
\hline & control & 845 & 113 & 88.1 & \\
\hline \multirow{2}{*}{ VI } & $4^{\text {h. }}$ & 727 & 146 & 83.3 & \multirow{2}{*}{+8.4} \\
\hline & control & 795 & 72 & 91.7 & \\
\hline
\end{tabular}

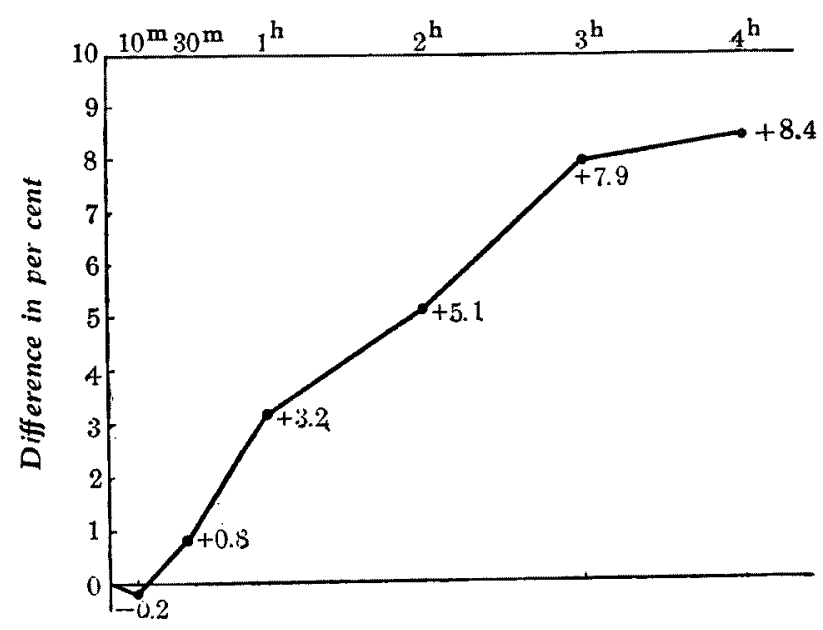

Time of exposure

Fig. 1 
In Table 2 , in the case of those nuclei which were apart from the cell membrane, the difference between the exposed material and the control is also given on the right of the figures denoting the percentage. These differences in per cent obtained in the six series of experiments r(-VI) are graphically shown in Fig. 1.

Result. As is seen from Table 2 and Fig. 1, the experiments show that when the material is exposed to ultra-violet rays, the viscosity of the cytoplasm first decreases slightiy, but then increases rapidly. This result agrees with that obtained by HeILBRUNN and Young in Arbacia (HeIlbRunN, L. V. and Young, R. A., The action of ultra-violet rays on Arbacia egg protoplasm. Physiol. Zool. Vol. 3, No. 3, 330-341. 1930). 